\title{
Peculiarities of formation and perspectives of development of the world market of the cruise industry
}

\author{
Natalya Logunova ${ }^{1, *}$, Svetlana Kalinkina ${ }^{2}$, Valentina Kulik $^{2}$, Natalya Lazitskaya $^{2}$ and Irina \\ Tregulova $^{2}$ \\ ${ }^{1}$ Kerch State Marine Technological University, 82 Ordzhonikidze Str., Kerch, Russia \\ ${ }^{2}$ Sevastopol Institute of Economics and Humanities (branch) of Crimean Federal University named \\ after V.I. Vernadsky, Sevastopol, Russia
}

\begin{abstract}
In the article, peculiarities of the modern cruise market proceeding from universal tendencies of development are considered by means of the analysis of dynamics of the world market of the cruise industry. The cruise product as a complex of services is presented in the form of three main subsystems: the services offered on the board of the vessel, the services consumed by tourists ashore, and the services connected with advance and realization of a cruise product and rendering assistance to passengers in the process of the organization of a transport travel. The main directions of analysis of the cruise business and its constituent elements are determined. It is established that the competitiveness of the cruise market depends not only on the share occupied on it by this or that company, but also by the indicators characterizing efficiency of functioning of any economic system, basic of which are: the level of income received as a result of the implementation of business activity, the number of the workers occupied in this direction of business and level of their labor productivity.
\end{abstract}

\section{Introduction}

Today, development of the economy of Russia is mainly defined by the level of development of the tourist industry. In this regard, issues of development of priority types of tourism to which the cruise tourism is concerned, which was widely adopted around the world and bringing considerable income in budgets of most of the European states acquire special actuality and timeliness, as from the positions of branch, and regional and national development.

Revival and development of the national cruise industry is impossible without studying of trends of the world cruise market and implementation of the leading practices in home practice.

\footnotetext{
*Corresponding author: sergiiblack@mail.ru
} 
The purpose of the article is identification of peculiarities of the modern cruise market proceeding from universal tendencies of development by means of the analysis of dynamics of the world market of the cruise industry.

\section{Results}

Cruises represent not just a kind of passenger transportation by water activities of transport, and specific, difficult on structure and the hi-tech type of a tourist product having unique consumer properties which, in turn, cause peculiarities of business activity on its creation, advance and implementation and also functioning of the cruise market in general [9].

The cruise market represents the system of the economic relations developing in the course of forming and further use of a cruise tourist product. At the same time the cruise product acts as the collective work combining efforts of a set of the enterprises and the industries involved in its creation, starting from the seaports providing an opportunity for reception of cruise vessels and finishing the enterprises of agriculture and mining industry that causes complexity of its providing. Besides, the quality of providing of the cruise product directly depends on skill level and competence of all personnel involved in process of its creation (designers, shipbuilders, workers of the food and easy industries, cruise operators, etc.).

For the last decade the basic consumer model of cruise tourism was replicated in relation to different segments of the market and naturally integrated with other types of tourism: recreational, adventure, ecological, cognitive, congress, etc. Considering unique properties of a cruise tour product, the cruise companies give preference to use of strategy of differentiation according to which the product is given such characteristics which will be appreciated by a large number of buyers. Owing to what, the marketing policy of the enterprises is directed to creation of the cruise products which are most adapted to the interests of the consumers traveling with the different purposes, representing different sectors of society and different demographic groups.

The cruise product as a backbone complex of services can be presented in the form of three main subsystems [9]:

- the services offered on the board of the vessel (placements, improving, public catering, trade, sports, etc.);

- the services consumed by tourists ashore during landing/disembarkation of passengers, the parking in ports of call (excursion, transport, cultural and entertaining, etc.);

- the services connected with advance and implementation of a cruise product and rendering assistance to passengers in the course of the organization of a transport travel (execution of visas and insurance, acquisition of plane tickets or the train, the order of excursions and hotels, provision of services of the translator, etc.).

Some of the major criteria providing a possibility of implementation of a sea cruise travel are technical equipment of the vessel intended for commission of a cruise which, at the same time, is subject to placement and the venue of leisure of tourists, and parametrical characteristics of port of call of the cruise liner that predetermines high extent of the specialization of a cruise product assuming several hierarchical levels. The first level includes development of special programs of stay of passengers on the board of the vessel and ashore during parking in port, the developed system of attractions and cultural and spectacular actions. The second level assumes the special equipment of the cruise vessel for service of the specific contingent of passengers. The third - building of the special cruise vessels answering to the concept of the corresponding cruise product including in terms of their navigable qualities. The fourth level consists in creation of conditions for safe reception of cruise vessels that predetermines building of seaports with the special 
terminals having big throughput and properly equipped for registration of passengers and their baggage, implementation of tourist formalities (customs fiscal sanitary immigration).

The system of implementation of cruise tours is poorly correlated with the systems of sale of land and other tours, has the special principles and the methodology which is significantly oriented to sale through computer networks and the Internet and differs in high performance. Considerable means are spent for advance of a tourist product, the condition of the market is constantly studied, special show programs are developed, and new categories of consumers are attracted [8].

Development of the international economic cooperation, its deepening and intensification caused strengthening of the economic exchange between the states relying on the growing international division of labor that led to multiple compression of economic space of the planet and globalization of the international market that could not but affect the market of the cruise industry. Globalization of the cruise market is shown not only in such tendencies as structurization on a global scale, but also in processes of vertical and horizontal integration of cruise corporations, their merges and absorption. Owing to what, today in the world cruise market three main corporations dominate: Carnival Corporation occupying $41.8 \%$ of all world cruise market, Royal Caribbean which possesses $23.3 \%$ of a share of the market, and MSC corporation - with $8 \%$ of shares of the cruise market. Processes of globalization of world economy allowed to reduce considerably costs of building of cruise liners and passenger terminals, and promoted increasing of cruise passenger traffic for the account of depreciation of cruises at the maximum maintaining quality of "elevated style of rest".

Peculiarities of formation and functioning of the world cruise market are presented in fig.1.

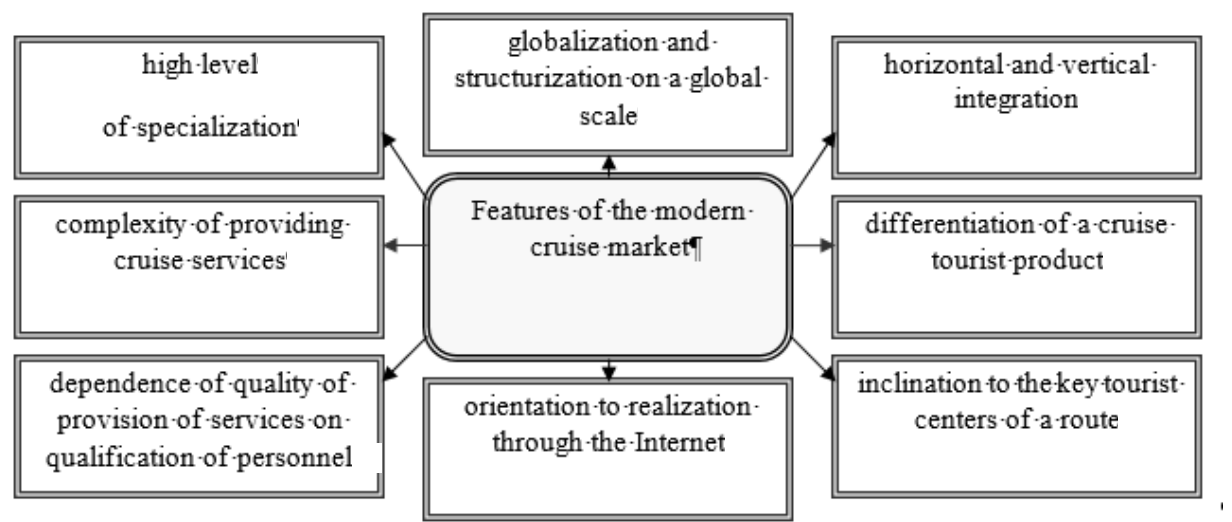

Fig. 1. Peculiarities of the modern world cruise market

It should be noted that for gaining strong market positions, competitive advantages of high degree of stability and a safe long-term financial position the relevant information base providing reliable qualitative information on the basis of which it is possible to predict trends of development of the cruise market and its basic elements is necessary. At the same time future condition of development considerably is defined by its past and the present states that cause a research of dynamics of development of the cruise market [11-16].

Analyzing specific features of the cruise tourist market, it is necessary to pay attention to the interconnected and interdependent elements creating basic conditions for its successful functioning and causing efficiency of cruise business in general (tab. 1). 
Table 1. The directions of the analysis of cruise business and its making elements.

\begin{tabular}{|c|c|}
\hline $\begin{array}{c}\text { Directions of the analysis } \\
\text { of cruise business }\end{array}$ & Making analysis elements \\
\hline Modern cruise processes & $\begin{array}{c}\text { History of emergence of cruises, image of a cruise travel, } \\
\text { competition and development of cruise brands }\end{array}$ \\
\hline $\begin{array}{c}\text { Realization of cruises and } \\
\text { cruise products }\end{array}$ & $\begin{array}{c}\text { Cruise market, cruise operators, tourist agents and sales agents, } \\
\text { marketing actions, meaning of loyalty and brand }\end{array}$ \\
\hline $\begin{array}{c}\text { Sea questions (problems) } \\
\text { Ship industry, pollution of sea waters, safety of life at the sea, } \\
\text { sanitation and purity, sea protection, financial responsibility and } \\
\text { the sea organizations }\end{array}$ \\
\hline Cruise geography & $\begin{array}{c}\text { Paramount and minor cruise regions, main destinations and } \\
\text { main attractions }\end{array}$ \\
\hline Planning of a route & $\begin{array}{c}\text { Peculiarities of a cruise destination, ports of destination, } \\
\text { motivations of cruise tourists, coastal excursions, logistics, } \\
\text { positioning and planning of a tourist's product }\end{array}$ \\
\hline Work on the board of the & $\begin{array}{c}\text { Roles and a duties, support of all divisions on the board, } \\
\text { management of hotel service, culture on the ship, attention to } \\
\text { workers, practice of hiring of personnel }\end{array}$ \\
\hline $\begin{array}{c}\text { Services for passengers of the } \\
\text { vessel }\end{array}$ & $\begin{array}{c}\text { Compliance to Standards, maintenance of quality, providing of } \\
\text { high-quality services on the board of the vessel }\end{array}$ \\
\hline $\begin{array}{c}\text { Management of supply } \\
\text { Stocks of food and provision of services on their timely } \\
\text { delivery, studying of consumer needs and requirements, the } \\
\text { organization and control of activity of service of supply }\end{array}$ \\
\hline Objects of management & $\begin{array}{c}\text { Administrative revenue, administration and administrative } \\
\text { premises, passenger service }\end{array}$ \\
\hline $\begin{array}{c}\text { Health, safety and protection } \\
\text { on the board }\end{array}$ & $\begin{array}{c}\text { Improving program on the vessel, safety and observance of the } \\
\text { mode, risk assessment }\end{array}$ \\
\hline $\begin{array}{c}\text { Cruise tourism } \\
\text { Identification of modern inquiries and problems }\end{array}$ \\
\hline
\end{tabular}

For the last decades the number of the tourists who went to a cruise increased more than in two times, and by 2017 were nearly 27 million people (fig. 2, tab. 2).

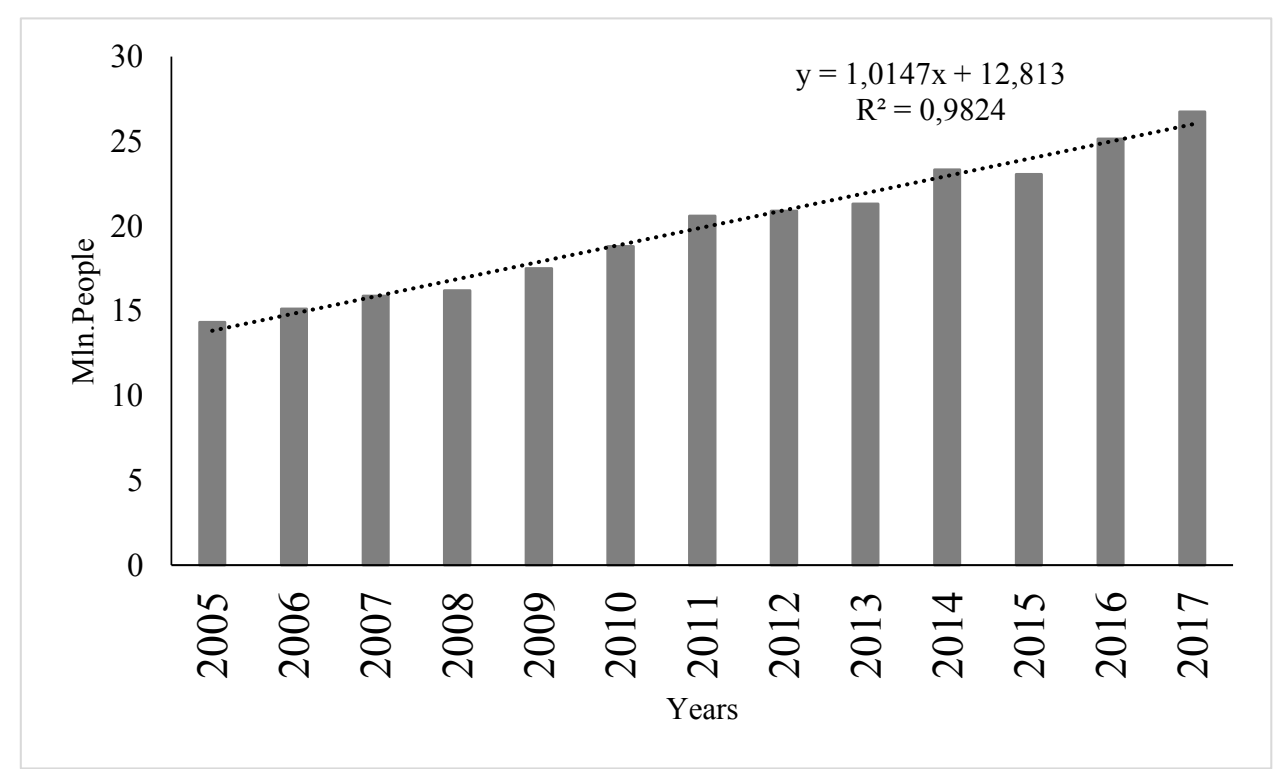

Fig. 2. Dynamics of development of the world market of the cruise industry. 
Table 2. The data characterizing dynamics of cruise passenger traffic for 2005-2017 [10].

\begin{tabular}{|c|c|c|c|}
\hline \multirow{2}{*}{ Years } & \multicolumn{3}{|c|}{ Number of the tourists who went to a cruise, million persons. } \\
\cline { 2 - 4 } & total & European tourists & tourists of North America \\
\hline 2005 & 14,32 & 3,15 & 9,67 \\
\hline 2006 & 15,11 & 3,44 & 10,08 \\
\hline 2007 & 15,87 & 4,05 & 10,25 \\
\hline 2008 & 16,20 & 4,46 & 10,09 \\
\hline 2009 & 17,50 & 5,00 & 10,20 \\
\hline 2010 & 18,80 & 5,54 & 10,78 \\
\hline 2011 & 20,60 & 6,18 & 11,50 \\
\hline 2012 & 20,90 & 6,23 & 11,64 \\
\hline 2013 & 21,31 & 6,4 & 11,82 \\
\hline 2014 & 23,34 & 6,39 & 12,04 \\
\hline 2015 & 23,06 & 6,46 & 12,00 \\
\hline 2016 & 25,15 & 6,79 & 12,26 \\
\hline 2017 & 26,75 & 6,96 & 12,87 \\
\hline $\begin{array}{c}\text { Average growth } \\
\text { rates, \% }\end{array}$ & 105,30 & 106,83 & 102,41 \\
\hline
\end{tabular}

It should be noted that the effectiveness of functioning of the market is defined not only by the share occupied on it by this or that company, but also by the indicators characterizing efficiency of functioning of any economic system basic of which are the level of income received as a result of implementation of business activity and number of the workers occupied in this direction of business (tab. 3).

Table 3. Dynamics of development of the European cruise market for 2005-2017.

\begin{tabular}{|c|c|c|c|}
\hline Years & $\begin{array}{c}\text { Total revenues of the } \\
\text { cruise industry, million } \\
\text { euro }\end{array}$ & $\begin{array}{c}\text { Quantity occupied in the } \\
\text { cruise industry, persons. }\end{array}$ & $\begin{array}{c}\text { Labor productivity of } \\
\text { workers, thousand } \\
\text { euro/persons. }\end{array}$ \\
\hline 2005 & 19,10 & 187,25 & 102,00 \\
\hline 2006 & 23,90 & 225,59 & 105,95 \\
\hline 2007 & 29,00 & 281,98 & 102,84 \\
\hline 2008 & 32,20 & 311,51 & 103,37 \\
\hline 2009 & 34,10 & 296,29 & 115,09 \\
\hline 2010 & 35,17 & 307,53 & 114,36 \\
\hline 2011 & 36,30 & 315,50 & 115,06 \\
\hline 2012 & 37,86 & 326,30 & 115,93 \\
\hline 2013 & 39,36 & 339,40 & 115,28 \\
\hline 2014 & 40,22 & 348,90 & 113,50 \\
\hline 2015 & 40,95 & 360,80 & 109,74 \\
\hline 2016 & 42,80 & 390,00 & 17,13 \\
\hline 2017 & 47,86 & 408,60 & 14,83 \\
\hline $\begin{array}{c}\text { Rates of } \\
\text { gain, basic, } \\
\%\end{array}$ & 150,58 & 118,21 & \\
\hline
\end{tabular}


Data of tab. 3 designated accurate tendencies of growth of the world cruise market. By the quickest rates the European cruise market developed: the number of the tourists who went to a cruise increased more, than 2 times, at the same time growth of total revenues of the cruise industry was more than $150 \%$, and the number of the workers involved in cruise business increased by 221.35 people (tab. 3 ).

If the global economic crisis which affected practically all spheres of economic activity made the impact on the North American cruise market, then the European cruise industry did not undergo significant changes, and rather, on the contrary, strengthened the competitive positions in the world market. Growth of passenger capacity and implementation of progressive technologies promoted reduction of specific expenses counting on one passenger seat that in turn allowed sea cruises to compete with land tours and increased financial stability of the European cruise business.

\section{Conclusions}

Thus, the analysis of trends of development of the world cruise market revealed the high capacity of the cruise sector caused by dynamic growth practically of all indicators characterizing efficiency of functioning of economic systems. It is established that the European cruise market the most economic and perspective in terms of further development. Taking into account results of diagnosing of the marketing environment and the consecutive analysis of prospects of growth of the cruise industry the main lines of the modern cruise market to which were concerned: high level of specialization; globalization and structurization on a global scale; horizontal and vertical integration; differentiation of a cruise tourist product; complexity of provision of services; dependence of quality of provision of services on qualification of personnel; orientation to realization through the Internet.

\section{References}

1. V.V. Zhikhareva, Development of methods of management and managing in transport 39(2), 13-21 (2012)

2. I.A. Golubkova Factors and regularities of structurization of the global cruise market (UkrDAZT, 2010)

3. Yu.V. Mikhaylova, A.M. Holodenko, Models of integration of participants of the market of cruise services (ONMU, 2008)

4. A. Demyanchenko, Bulletin of Berdyansk university of management and business 3(19), 21-32 (2012)

5. N. O. Zatsepina, The history of emergence and the current state of tourism in the world (Scientific works of historical department of Zaporizhsky national university, 2012)

6. O.S. Lyakhovska, Collection of scientific works: scientific notes of Rivnensky government humanitarian university 2, 25-30 (2011)

7. M.B. Birzhakov, V.I. Nikiforov, Tourism industry: Transportation (Nevsky Fund, 2003)

8. O.Ya. Osipova, Transport service of tourists: education guidance (Akademiya, 2004)

9. S. Shpilko, N. Androsova, R. Chudarev, Sea cruises: theory and practice: education guidance (Sovetsky Sport, 2012)

10. V. Budnik, S. Chernyi, Procedia Engineering 150, 2150-2156 (2016) 
11. N. Logunova, L. Aleksahina, S. Chernyi, 2017 International Conference "Quality Management,Transport and Information Security, Information Technologies" $(I T \& Q M \& I S)$ (2017)

12. A. Nyrkov, A. Zhilenkov, S. Sokolov, S. Chernyi, Automation and Remote Control 791, 195-202 (2018)

13. A. Zhilenkov, S. Chernyi, Procedia Engineering 100, 1247-1252 (2015)

14. S. Chernyi, N. Logunova, L. Aleksahina, 2018 IEEE Conference of Russian Young Researchers in Electrical and Electronic Engineering (EIConRus) (2018)

15. S. Chernyi, N. Logunova, L. Aleksahina, 2018 IEEE International Conference "Quality Management, Transport and Information Security, Information Technologies" (IT\&QM\&IS) (2018) 